\title{
The Politics of Historical Thinking
}

Historical thinking has a politics that shapes its ends. While at least two generations of scholars have been guided into their working lives with this axiom as central to their profession, it is somewhat of a paradox that historiography is so often nowadays seen as a matter of intellectual choices operating outside the imperatives of quotidian politics, even if the higher realms of ideological inclinations or historiographical traditions can be seen to have played a role. The politics of historical thinking, if acknowledged at all, is seen to belong to the realms of nonprofessional ways of the instrumentalisation of the past.

This series seeks to centre the politics inherent in historical thinking, professional and non-professional, promoted by states, political organisations, 'nationalities' or interest groups, and to explore the links between political (re-)education, historiography and mobilisation or (sectarian?) identity formation. We hope to bring into focus the politics inherent in historical thinking, professional, public or amateur, across the world today.

\section{Editorial Board:}

Brigitta Bernet, University of Trier

Lutz Raphael, University of Trier

Benjamin Zachariah, University of Trier

\section{Advisory Board:}

Caroline Arni, University of Basel

Amar Baadj, University of Bonn

Berber Bevernage, University of Ghent

Federico Finchelstein, New School for Social Research, New York

Kavita Philip, University of California Irvine

Ilaria Porciani, University of Bologna

Dhruv Raina, Jawaharlal Nehru University, New Delhi

Jakob Tanner, University of Zürich 
